\title{
Cellulase Activity of a Lentinula edodes (Berk.) Pegl. Strain Grown in Media Containing Carboximetilcellulose or Microcrystalline Cellulose
}

\author{
José Antônio de Sousa Pereira Júnior ${ }^{1 *}$, Marcos José Correia ${ }^{2}$ and Neiva Tinti de Oliveira ${ }^{1}$ \\ 1 Departamento de Micologia; Centro de Ciências Biológicas; Universidade Federal de Pernambuco; \\ nto@npd.ufpe.br; 50670-420; Recife - PE - Brazil. ${ }^{2}$ Departamento de Morfologia e Fisiologia Animal; \\ Universidade Federal Rural de Pernambuco; Recife - PE - Brazil
}

\begin{abstract}
Endoglucanase and exocellobiohydrolase produced b Lentinula edodes (Berk.) Pegl. strain thatt was cultivated in carboxymetilcellulose (CMC) or microcrystalline cellulose (Avicel) liquid media. The concentration and type of cellulose influenced the enzyme activity and production. Extra-cellular cellobiase activity was not detected in CMC or Avicel media. This enzyme was detected in mycelial extracts only. With 1.7\% Avicel liquid medium, the strain did not produce exocellobiohydrolase, but $74 \mu \mathrm{mol}$ RBBR/mg protein $/ \mathrm{min}$ was detected with $0.5 \%$ Avicel. The substitution of Avicel by $0.5 \%$ CMC reduced this activity. Endoglucanase also had maximum activity in $0.5 \%$ Avicel medium (approximately $820 \mathrm{UI} / \mathrm{mg}$ protein) after $96 \mathrm{~h}$ incubation. In supernatants from 0.5\% CMC, the maximum activity attained was $200 \mathrm{UI} / \mathrm{mg}$ protein only.
\end{abstract}

Key words: Lentinula edodes, cellulase, liquid medium cultivation

\section{INTRODUCTION}

During the period between 1986 to 1991 , the world production of Shiitake mushroom [Lentinula edodes (Berk.) Pegl.] increased 64.4\% (Miles and Chang, 1997). The greatest Shiitake producers of Brazil are located in the Southeast region, mainly in São Paulo State. Although this region has large forest reserves, mainly of Eucalyptus species, the use of lignocellulosic residues can be a more economically-viable process for the large scale cultivation due to rapid bioconversion (Buswell et al., 1996). Towards this, various strategies have been developed in many parts of Asia to utilize part of the vast quantities of waste lignocellulose generated through the agricultural, forestry and food processing industries (Chang and Miles, 1991).

The utilisation of lignocellulosic substrates by mushrooms depends on the production of a pool of hydrolytic and oxidative enzymes able to convert lignocellulosic compounds, of high molecular weight, into low molecular molecules that can be assimilated and converted into biological energy (Buswell and Chang, 1993). The aim of this workwas to study the profile of the cellulolytic enzymes exocellobiohydrolase (EC. 3.2.1.91), endoglucanase (EC. 3.2.1.4) and cellobiase (EC. 3.2.1.21) produced in cellulolytic media by L. edodes.

\footnotetext{
* Author for correspondence
} 


\section{MATERIALS AND METHODS}

\section{Organism and culture conditions}

Lentinula edodes (Berk.)Pegl., strain CC17 was obtained from the Laboratório de Cogumelos Comestíveis, Centro Nacional de Recursos Genéticos e Biotecnologia - CENARGENEMBRAPA, and maintained at $5^{\circ} \mathrm{C}$ on MaltExtract-Agar (MEA) slants with periodic transfer. To determine cellulolytic enzyme production by $L$. edodes, the fungi was cultivated on MEA Petri dishes and five $\mathrm{mm}$ diameter culture edge plugs were cut off and transferred (in three sets) $250 \mathrm{ml}$ Erlenmeyer flasks containing $50 \mathrm{ml}$ defined medium modified from Soundar and Chandra (1998) (SC medium), containing (g/l): Avicel or CMC 5g, Peptone 1g, $\mathrm{Ca}\left(\mathrm{NO}_{3}\right)_{2} .4 \mathrm{H}_{2} \mathrm{O} 5.5 \mathrm{~g}$, $\mathrm{KH}_{2} \mathrm{PO}_{4} \quad 1.3 \mathrm{~g}, \quad \mathrm{MgSO}_{4} .7 \mathrm{H}_{2} \mathrm{O} \quad 0.5 \mathrm{~g}$, plus $1 \mathrm{ml}$ nutrient solution. A culture was also carried out in a Jurasek and Paice (1988) medium (JP medium), containing Avicel (17g) and peptone (20g). The medium components were dissolved in deionized water and sterilized at $121^{\circ} \mathrm{C}$ for $30 \mathrm{~min}$. The flasks were incubated on rotatory shaker (FANEN®) for 10 days at $150 \mathrm{rpm}$ and $28.0 \pm$ $1.0^{\circ} \mathrm{C}$. Aliquots were collected each two days, centrifuged and supernatants used for enzyme assays. Chemicals were obtained from SIGMA/MERCK.

\section{Enzyme assays}

Exocellobiohydrolase, endoglucanase and cellobiase (EC. 3.2.1.21) activities were determined according to Wood and Bhat (1988) procedure. In Avicelase assays, $1 \mathrm{ml}$ supernatant was pipetted to $10 \mathrm{ml}$ test tubes and $1.5 \mathrm{ml} \mathrm{RBBR}$ Avicel suspension containing $100 \mathrm{mg} / 3 \mathrm{ml}$ was added. The mixture was incubated for $30 \mathrm{~min}$. at $50^{\circ} \mathrm{C}$, after which the tubes were placed in a boiling water bath to stop reaction. The hot suspension was centrifuged and the supernatant was read in spectrophotometer at $595 \mathrm{~nm}$. The activity was expressed in $\mu \mathrm{mol}$ of RBBR, calculated from its molar extinction coefficient $\left(5901.1 \mathrm{~mol}^{-1} \cdot \mathrm{cm}^{-1}\right)$. The endoglucanase activity was determined by incubating $0.5 \mathrm{ml}$ of supernatant conveniently diluted with citrate buffer ( $\mathrm{pH} 4.8$ ) in a $25 \mathrm{ml}$ test tube for $30 \mathrm{~min}$ at $50^{\circ} \mathrm{C}$. After incubation, $3 \mathrm{ml}$ DNSA reagent was added and the solution was boiled for $5 \mathrm{~min}$. The absorbance was measured at $540 \mathrm{~nm}$ and the glucose content was obtained by comparing to a glucose standard graph prepared by the same procedure. The enzyme activity was expressed in $\mathrm{IU} / \mathrm{mg}$ protein. Cellobiase was measured by using p-Nitrophenil- $\beta$-D-glucoside method. The supernatant protein content was determined by Bradford (1976) methodology. One millilitre of pNitrophenyl- $\beta$-D-glucoside substrate was pipetted into a test tube along with $1.8 \mathrm{ml}$ of acetate buffer $\mathrm{pH} 4.8$ at $50^{\circ} \mathrm{C}$. Diluted enzyme $(200 \mu \mathrm{l})$ was added and the mixture incubated at $50^{\circ} \mathrm{C}$ for 30 min. Glycine buffer, pH 10.8 was added to stop reaction and the liberate p-nitrophenol was measured at $430 \mathrm{~nm}$ against a standard curve of $\mathrm{p}$ nitrophenol. The unit of activity was expressed in $\mu \mathrm{mol}$ p-nitrophenol/min.

\section{RESULTS AND DISCUSSION}

Lentinula edodes CC-17 showed endoglucanase activity in supernatants of all culture media examined (JP and SC media). However, exocellobiohydrolase showed only activity in SC medium. Celobiase activity was not detected in either JP or SC media. This enzyme was detected in mycelial extracts only.

Buswell et al. (1996) and Leatham (1985) L. edodes as reported as a weak hydrolytic enzyme producer when cultivated on microcrystaline cellulose media. Many reports pointed the lack of detection of cellulases of this fungi. Reducing sugar was not found in all supernatant samples collected. This behaviour suggest as a inherited characteristic of the strain.

The concentration and type of cellulose influenced the exocellobiohydrolase activity. At $1.7 \%$ Avicel (JP medium), no exocellobiohydrolase was detected. However, at 0.5\% Avicel (Fig.1), two peaks were obtained at each 4 days of incubation, with the highest peak around $74 \mu \mathrm{mol} \mathrm{RBBR} / \mathrm{mg}$ protein/min. When Avicel was replaced by CMC, the activity decreased to less than the half of activity reached with Avicel. 


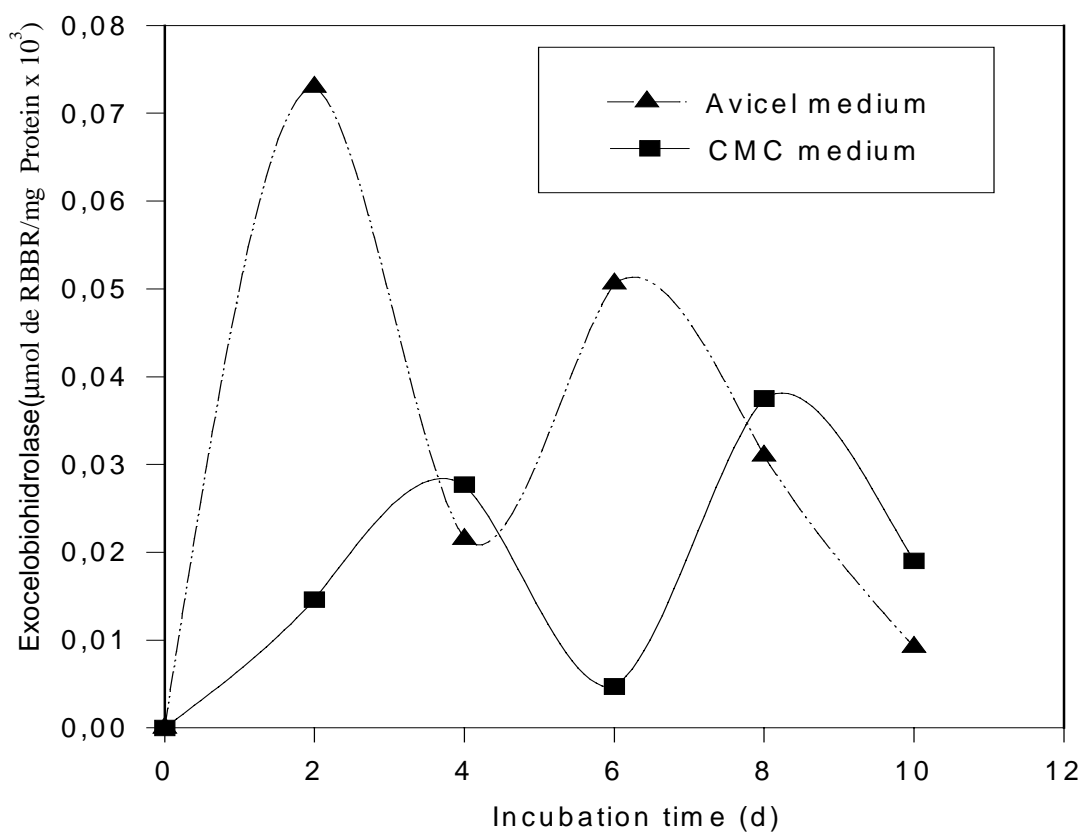

Figure 1 - Exocelobiohydrolase activity of Lentinula edodes (Berk.) Pegl., strain CC-17, on Avicel and CMC (SC medium).

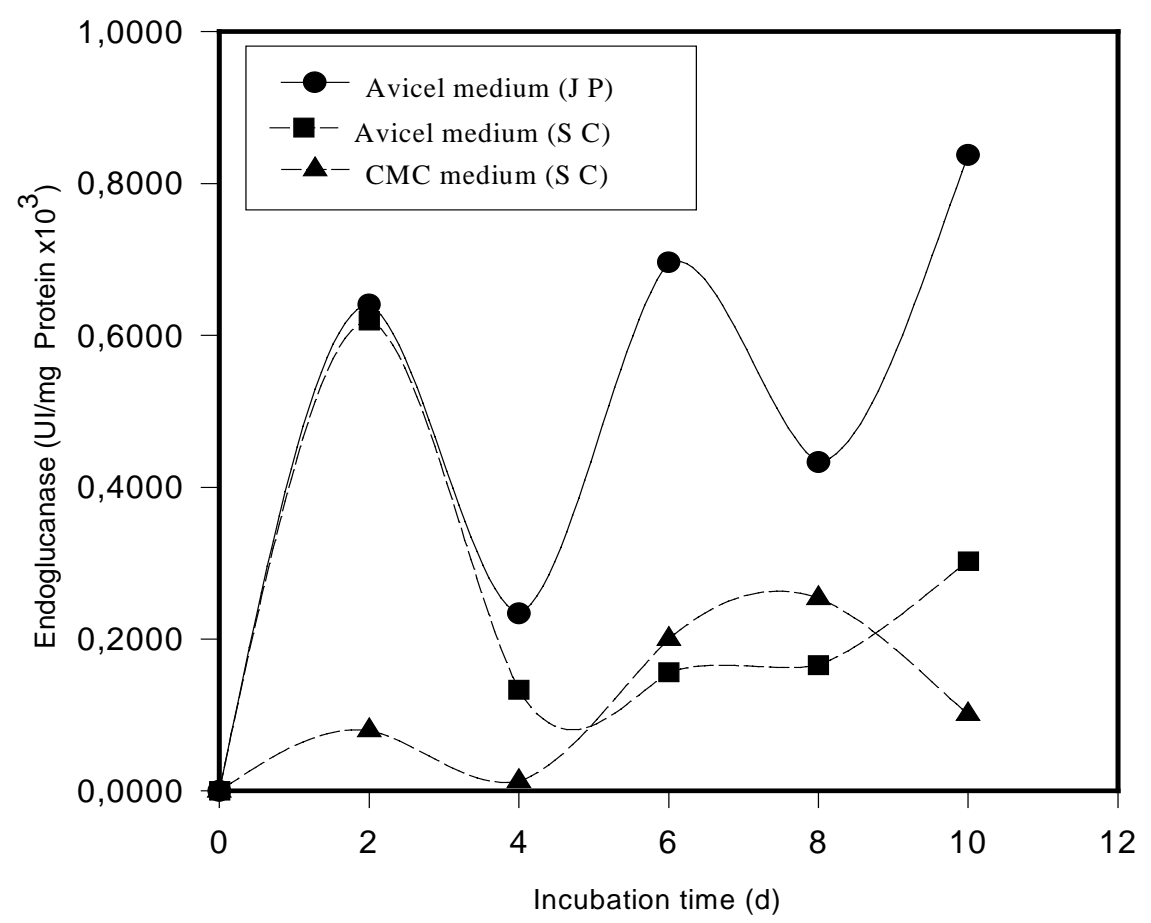

Figure 2 - Endoglucanase activity of Lentinula edodes (Berk.) Pegl., strain CC-17, on Avicel (JP media and SC media) and CMC (SC medium). 
In both substrates (Avicel and CMC), the cultures showed two activity peaks followed by a activity decrease. This fact can be explained by the following: (a) substrate heterogeneity, such as the substrate portions more easily degraded are firstly hydrolysed; (b) end product inhibition and (c) thermal inativation and irreversible adsortion of part of enzyme by the substrate (Mandels and Reese, 1960).

Endoglucanase (EC 3.2.1.4) activity was distinct at different cellulose concentrations and composition (Fig.2). In supernatants obtained from 1.7\% Avicel (JP medium) was $820 \mathrm{UI} / \mathrm{mg}$ protein. At $0.5 \%$ Avicel medium (SC medium), this enzyme showed a single peak $(620 \mathrm{UI} / \mathrm{mg}$ protein $)$ at $48 \mathrm{~h}$ incubation. In CMC medium, endoglucanase showed the lowest activity (maximum $200 \mathrm{UI} / \mathrm{mg}$ protein).

The absence of detectable glucose in supernatants of both culture media suggested a effect of substrate on the synthesis and cellulase excretion, without a end product repression, since the glucose inhibition level $0.5 \%$, and restored when $90 \%$ of glucose was consumed (Mandels and Reese, 1960). Non cellobiase activity was detected in all supernatants collected.

\section{ACKNOWLEDGEMENTS}

This work was supported by a grant from Banco do Nordeste do Brasil - BNB/FUNDECI and Coordenação de Aperfeiçoamento de Pessoal de Nível Superior - CAPES. We thank to Departamento de Morfologia e Fisiologia - DMFA of UFRP for providing the laboratories were this research was done.

\section{RESUMO}

Neste trabalho foram estudadas as atividades de endoglucanase, exocelobiohidrolase e celobiase em uma linhagem de Lentinula edodes (Berk.) Pegl. cultivada em meio líquido contendo carboximetilcelulose (CMC) ou celulose microcristalina (Avicel). Foram detectadas as atividades de endoglucanase e exocelobiohidrolase no sobrenadante das culturas crescidas tanto em meios contendo CMC como nos meios contendo Avicel, sendo observada a influência da concentração e do tipo de celulose. Não foi detectada atividade de celobiase nos sobrenadantes, sendo a mesma detectada somente no extrato micelial. Com uma concentração de $1,7 \%$ de Avicel, a linhagem estudada não demonstrou atividade de exocelobiohidrolase. Porém, à concentração de $0,5 \%$ obteve-se uma atividade de $74 \mu \mathrm{mol}$ de RBBR/mg de proteína/min. Com a substituição de Avicel por CMC a $0,5 \%$, a atividade de exocelobiohidrolase foi reduzida a menos de $50 \%$. A máxima atividade de endoglucanase em sobrenadantes obtidos em meio com Avicel a $0,5 \%$ foi em torno de 800 UI/mg de proteína, após 96 horas de cultivo. Em sobrenadantes obtidos de meio com CMC, a atividade desta enzima foi de apenas $200 \mathrm{UI} / \mathrm{mg}$ de proteína.

\section{REFERENCES}

Bradford, M. M. (1976), A rapid and sensitive method for the quantification of microgram quantities of protein utilizing the principle of protein dye-binding. Anal. Biochem., 72, 248-254.

Buswell, J. A. and Chang, S. T. (1993), Fungal and substrate-associated factors affecting the growth of individual mushroom species on different lignocellulosic substrates. In: Chang, S. T.; Buswell, J. A. and Chiu, S. W. (eds.). Hong Kong : Chinese University Press. pp. 141-150.

Buswell, J. A.; Cai, Y. J.; Chang, S. T.; Peberdy, J. F.; $\mathrm{Fu}$, S. Y. and $\mathrm{Yu}, \mathrm{H}$. S. (1996), Lignocellulolytic enzyme profiles of edible mushroom fungi. World $J$. Microbiol. Biotechnol., 12, 537-542.

Chang, S. T. and Miles, P. G. (1991), Recent trends in world production of cultivated mushrooms. Mush. J., 503, 15-18.

Correia, M. J.; Pereira Jr., J. A. S.; Santos, J. C. and Cavalcanti, M. A. Q. (1998), Use of Remazol Blue Dyed Avicel for the determination of cellulolytic activity Basidiomycetes. Rev. Microbiol., 29, 286-288.

Jurasek, L. and Paice, M. G. (1988), Xylanase A of Schizophyllum comune. In: Wood, W. A. and Kellog, S. T. (eds.). Methods in enzimology. San Diego : Academic Press, 160, ch 83.

Leatham, G. (1985), Extracellular enzymes produced by the cultivated mushroom Lentinus edodes during degradation of a lignocellulosic medium. Appl. Envir. Microbiol., 50, 859-867

Mandels, M. and Reese, E. T. (1957), Induction of cellulase in Trichoderma viride as influenced by carbon sources and metals. J. Bacteriol., 73, 269-278.

Mandels, M. and Reese, E. T. (1960), Induction of cellulase in fungi by cellobiose. J. Bacteriol., 79, 816-826. 
Miles, P. G. and Chang, S. T. (1997), Mushroom biology: concise basics and current developments. Singapore: World Scientific, 194 pp.

Soundar, S. and Chandra, T. S. (1988), Production of cellulase and detection of Avicel-adsorbing carboxymethylcellulase from a mesophilic fungus Humicola grisea Fb. Enzyme Microbiol. Technol., 10, 368-374.

Wood, T. M. and Bhat, K. M. (1988), Methods for measuring cellulase activities. In: Wood, W. A. and Kellog, S. T. (ed.). Methods in enzymology. San Diego : Academic Press, 160, ch 9.

Received: April 05, 2001; Revised: October 30, 2001; Accepted: October 31, 2002. 